\title{
木造住宅の簡易な耐震診断法に 関する研究 \\ STUDY ON SIMPLIFIED SEISMIC DIAGNOSIS OF WOODEN HOUSE
}

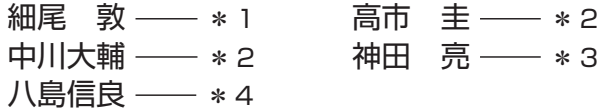

キーワード :

木造住宅, 耐震診断, 耐震性能, 地域防災, Google マップ

Keywords:

Wooden house, Seismic diagnosis, Seismic performance, Regional disaster prevention, Google map

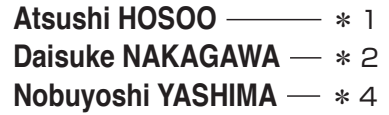

Atsushi HOSOO $-* 1$

Daisuke NAKAGAWA - $* 2$

Nobuyoshi YASHIMA - * 4

This paper proposes a simplified seismic diagnosis to rapidly gather a lot of data for the earthquake resistant performance of wooden houses and describes the verification of its accuracy and indicates some examples to gather data by means of this diagnosis. In this diagnosis, the data for wooden houses are gathered by visual obtainment of exterior. We can choose in two options for how to conduct visual obtainment of exterior. One option is to obtain data by direct visual on-the-spot investigation. The other is to obtain data from the site of street view in the Google. From the results, it is found that one of the important factors that accuracy goes down is error when some lengths on houses are evaluated by visual obtainment of exterior, and that a lot of data can be gotten by means of this diagnosis.

\section{2. 簡易な耐震診断法の提案}

1.はじめに

1995 年に発生した阪神・淡路大震災では 6000 人を超える多くの 尊い命が失われた。そのほとんどは，木造住宅の倒壊による圧死， または火災による焼死であった。倒壊した木造住宅のほとんどは, 新耐震設計法施行(1981 年)以前に建てられた屋根が重く，壁量が不 足している，いわゆる，既存不適格のものである。しかし，震災か ら 15 年経過した現在でもこれら既存不適格木造住宅は全国各地に 約 1000 万戸 ${ }^{1)}$ も存在しており，早急な対応が望まれる。

これらを教訓として，震災直後から既存木造住宅に対する耐震診 断と補強の技術の開発 ${ }^{2)}$ が行われている。これは, 地震防災の最も 重要な人命の尊重という立場から当然であろう。個々の住宅の耐震 性能を把握することは住宅の耐震性能を向上させ，その倒壊を防ぐ というだけでなく地域防災の面からも有益である。例えば，既往の 研究において震度と住宅の倒壊率を示した被害関数の推定 ${ }^{3)}$, 避難 所の容量と避難者数の推定 ${ }^{4)}$ などにも個々の住宅の耐震性能に関す る統計量が用いられている。しかし，そのような統計量は現在，極 めて少なく，その原因を調べてみると住宅の耐震診断を短期間に多 量に実施する手段がほとんどないという明解な理由に辿りつく。

以上を踏まえ，本論文は住宅の耐震性能に関する多くの情報を短 期間に収集するための簡易な耐震診断法を提案し，その精度を検討 する事を目的とする。また，その診断法を用いて 4 つの地区で住宅 の耐震性能に関する情報収集を行った例を示す。提案する診断法は, 一般診断法 ${ }^{2)}$ 改良した手法であり，短時間で多くの住宅を診断で きるように工夫されている。

本診断法の基本的考え方は, 一般診断法による。今まで住宅の耐 震診断があるにも関わらず，地域全体の住宅の耐震性能に関する統 計量がほとんど収集されていないのは, 既存の耐震診断法がその精 度が高い反面 1 つの住宅を診断する労力と手間が掛かっていたため である。具体的には, 図面の入手や内観の現地調查などを必要とす る。ここで本診断法は診断の対象とする住宅の情報を外観目視のみ により収集し，労力や手間をできるだけ軽減するように工夫した。 本診断法のフローを図 1 に示す。この方法の行程は目視による外観

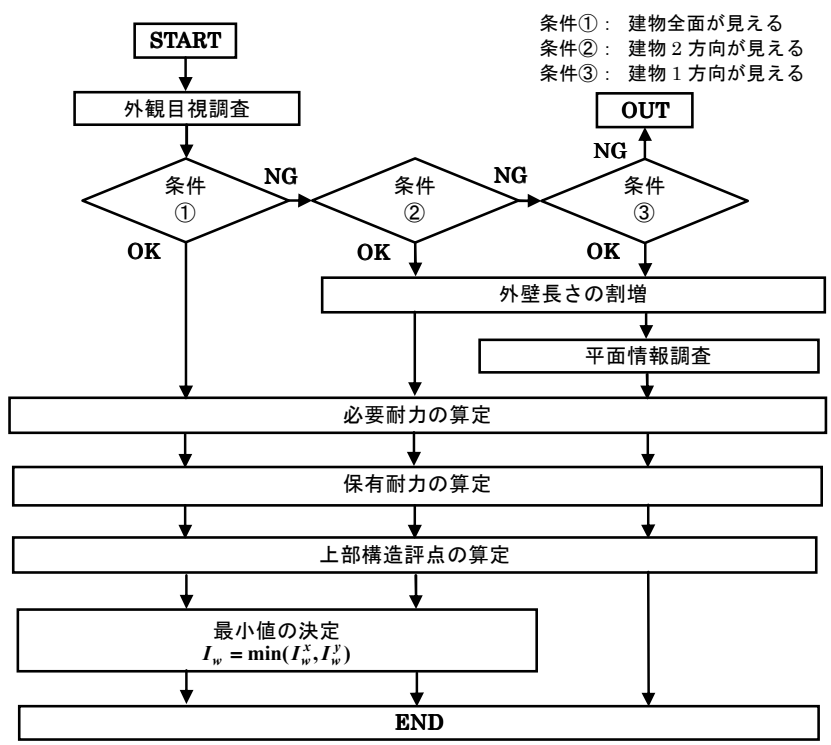

図 1 本診断法のフローチャート

\footnotetext{
'1 㑣地震工学研究所 (元 日本大学大学院生産工学研究科建築工学専攻) 修士 (工学)

（T275-8575 千葉県習志野市泉町 1-2-1）

日本大学大学院生産工学研究科建築工学専攻

日本大学生産工学部建築工学科 教授・博士（工学）

4 日本大学理工学部海洋建築工学科 非常勤講師 $\cdot$ 工博
}

"1 Jishin Kougaku Kenkyusyo, Inc., Ms. Eng.

Graduate Student, Graduate School of Industrial Tech., Nihon Univ.

3 Prof., Dept. of Architectural Engineering, College of Industrial Tech., Nihon Univ., Dr. Eng.

4 Part-time Lecturer, Dept. of Oceanic Architectural Engineering, College of Science and Tech., Nihon Univ., Dr. Eng. 
調查と上部構造評点 $I_{w}$ の算定に大別できる。

\section{1 外観目視による対象建物の調査}

本診断法の調査では診断者が外観目視によって住宅の耐震診断に 必要な情報を収集する。収集する情報は, 建物長さ $L_{j}$ や無開口外壁 のトータル長さ $e_{e}^{j}$, 屋根の種類, 築年の情報である。ここで, 添え 字 $j$ は $x, y$ 方向, $w$ は壁, $e$ は外側を示す。外観目視調查の方法と しては, 現地に赴き直接目視により情報を得る方法(図 2)と, 近年, 普及しつつある Google マップより情報を得る方法(図 3)を考えてい る。なお, この行程は, 本診断法の簡便性を大きく支配しているた め，この他にもつと効率良く情報を得る手法があればその手法を用 い診断法の改良が行える。

外観目視調查では, 過去の地震被害から倒壊した木造住宅はその ほとんどが 1 階部分の倒壊であること ${ }^{5)}$ が分かっているため, 2 階 建て以上の木造住宅の場合であっても 1 階部分を目視の対象とする。

\section{2 上部構造評点の算定}

上部構造評点 $I_{w}$ は保有耐力 $P_{d}$ と必要耐力 $Q_{r}$ の比で表わされる。 $P_{d}$ と $Q_{r}$ は外観目視調查で得られた情報より算定する。以下に, そ の算定手順を示す。

$Q_{r}$ は, 地震時に作用する地震力と等価な值であり, 床面積当たり の必要耐力 $\gamma_{r}$ に 1 階の床面積 $A_{f}$ を乗じて算出する。

$$
Q_{r}=A_{f} \cdot \gamma_{r}
$$

ただし，

$$
A_{f}=L_{x} \cdot L_{y}
$$

ここで， $\gamma_{r}$ は目視より得られた屋根の種類と階高から文献 1 の一 般診断法を参考に算定する。

次に, $P_{d}$ は建物が有する耐力であり, 壁の耐力 $P_{w}$ と柱などのそ の他の部材の耐力 $P_{c}$ の和に住宅の劣化度による低減係数 $D$ を乗じ て求める。以下にその算定式を示す。

$$
P_{d}^{j}=\left(P_{w}^{j}+P_{c}^{j}\right) \cdot D
$$

ただし，

$$
\begin{gathered}
P_{w}^{j}={ }_{e} P_{w}^{j}+{ }_{i} P_{w}^{j} \\
{ }_{e} P_{w}^{j}=\bar{C} \cdot e_{e} l_{w}^{j} \\
{ }_{i} P_{w}^{j}=r_{1} \cdot P_{w}^{j} \\
P_{c}^{j}=r_{2} \cdot Q_{r} \\
j=x, y
\end{gathered}
$$

ここで, $P$ は耐力, 添え字 $c$ は壁以外の柱などを示す。また, 添 え字 $i$ は内側を示す。さらに, $\bar{C}$ は外壁の単位長さあたりの耐力, $r_{1}$ は外壁の総耐力と内壁の総耐力の比, $r_{2}$ は $Q_{r}$ に対して壁以外の柱な どの部材が負担する耐力の割合を示す。過去の診断実績から $r_{1}$ は $r_{1}=1.0 \cong 0.53 / 0.47, r_{2}$ は文献 1 より $r_{2}=0.25$ とした。また, $\bar{C}$ は $r_{1}$ と同様に $\bar{C}=2.94(\mathrm{kN} / \mathrm{m})$ とした。 $L_{j}, e_{e}^{j} l_{w}^{j}$ を Google マップのストリ ートビュー上から目視情報を得て算定する場合には, 道路側からの 1 面の写真しか掲載されてないことが多く(図 3 中 a)), 建物外観 4 面が必ずしも全て目視可能であるとは限らない。このような場合に は, 道路直交側長さを道路側面から判断できないことから道路直交 側長さは屋根伏せ面が見える航空写真を利用した平面情報(図 3 中 b))より数量化する。また, ${ }_{e} l_{w}^{j}$ は $j$ 方向 2 面の総量であるため道路側 面だけの無開口外壁長さ $l_{w}^{j s}$ から $e_{l}^{j}$ を下式によって予測する。

$$
e_{w}^{j}=\left(1+r_{3}\right){ }_{e} l_{w}^{j s}
$$

ここで， $r_{3}$ は道路面の壁長さに対する反対面の壁長さの割合，添

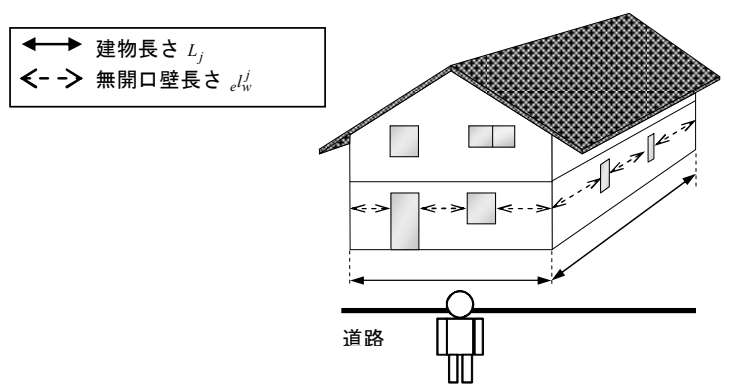

図 2 直接目視による外観目視調査

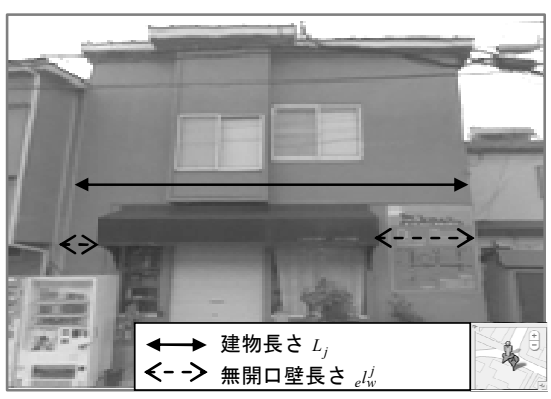

a) ストリートビュー

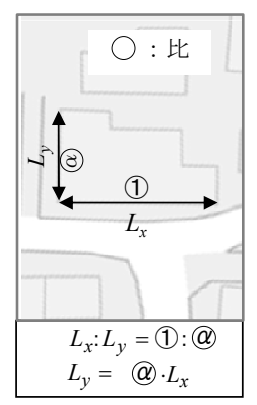

b）平面情報

\section{図 3 Google マップによる外観目視調査}

え字 $s$ は道路側を示す。今回, 筆者らが行った過去の診断実績から $r$ は， $r_{3}=1.48$ とした。また， $D$ は調査より得られた築年の情報で評 価する。具体的には外壁のひび割れや腐朽などの傷み具合からおお よその築年を推測し，木造住宅の耐用年数の約半分である築年 10 年未満を 1.0 , 新耐震設計法施行以前の建物である築 30 年以上を 0.7 , その間の築年 10 年以上 30 年末満を 0.85 とした。

以上より, 算定した $Q_{r}, P_{d}$ を基に, 式(4a), (4b)により $I_{w}$ を算定 する。

$$
\begin{gathered}
I_{w}=\min \left(I_{w}^{x}, I_{w}^{y}\right) \\
\text { ただし, } \\
I_{w}^{j}=P_{d}^{j} / Q_{r} \\
\text { ここで, 式(4a)において建物 } x, y \text { 方向の } 1 \text { 方向でしか目視できな } \\
\text { かった場合は, その方向をもって } I_{w} \text { とする。 }
\end{gathered}
$$

\section{3. 簡易な耐震診断法の精度の検討}

\section{1 精度の検討方法}

本診断法の結果の精度を確保することは, これらの診断法を用い て地域防災計画を行う上で重要なことである。このため本章では, 本診断法の精度を統計解析により検討する。

本診断法の算定手順をよく吟味すると, 結果の精度が低下寸る要 因は, 行程を簡略化したことにより誤差が含まれること, 目視によ る情報に誤差が含まれることなどが考えられる。これらの他にも要 因は考えられるが, 今回は, 特にこの 2 つ誤差が支配的であると 考え, この $2 つ に$ 着目して精度の検討を行う。そこで, 一般診断を 実施した 128 件の木造住宅の $I_{w}$ を本診断法で求めた值と比較してそ の基本的精度を検討する。本診断法と一般診断法により算定される $I_{w}$ の差は, 算定過程を簡略化し $I_{w}$ を略算することで生じる誤差(以 下, 略算誤差)と目視の際に情報を見誤ることで $I_{w}$ に生じる誤差(以 
下，目視誤差)に大別できる。例えば, 略算誤差には, $\bar{C}$ と実際の外 壁の耐力の差がある。目視誤差には， $L_{j}$ などを評価する際に生じる 長さの見誤りによるものの他, $\gamma_{r}$ や $D$ を評価する際に生じるものが あるが，今回は, 誤差に対して支配的と考えられる長さの見誤りに よる誤差(以下，見誤り誤差)に着目する。 $I_{w}$ から略算誤差のみを抽 出するには, 見誤り誤差をゼロにして $I_{w}$ を求め, 一般診断法により 求めた $I_{w}$ と比較すれば良い。見誤り誤差をゼロにするため, 本診断 法における耐震診断に必要である建物長さ $L_{j}$ や無開口外壁のトー タル長さ ${ }_{e} l_{w}^{j}$, 屋根の種類, 築年の情報を図面から読み取り, 本診断 法の $I_{w}$ の算定方法を適用し $I_{w}$ を算定 (以下, この方法を図面診断 法)する。また, 目視誤差のみを抽出するには本診断法と図面診断法 とを比較する。

本来ならば，直接目視により情報を得て $I_{w}$ を求める方法(以下， 直接目視診断法), あるいは Google マップの情報を得て $I_{w}$ を求める 方法(以下, Net 目視診断法)で一般診断を実施した住宅の $I_{w}$ を求め たいと考える。しかし, その 128 件の住宅が広域に点在しているこ と, Google マップではその住宅のうち少数しか確認できないことな どから 128 件の住宅に対する 2 つの手法の実施は困難である。した がって, 任意の住宅の $L_{j},{ }_{e} l_{w}^{j}$ を直接目視, Google マップより実際 に数量化し, そのばらつきを統計的に求めた。 $L_{j}, e_{w}^{j}$ は, 誤差を 含んだ長さ $L^{\prime}$ とし, 下式により算定する。なお， $L^{\prime}$ は対数正規分布 に従うものとする。

$$
L^{\prime}=\exp (\lambda+\xi \cdot r)
$$

$$
\text { ただし， }
$$

$$
\begin{aligned}
\lambda & =\ln \bar{\mu}-0.5 \cdot \xi^{2} \\
\xi & =\sqrt{\ln \left(1+\overline{\delta^{2}}\right)} \\
\bar{\mu} & =L \cdot(1+\alpha) \\
\alpha & =\overline{\Delta L} / L
\end{aligned}
$$

ここで, $\lambda, \quad \xi$ は読み取り長さの対数の平均值と標準偏差, $\bar{\mu}$, $\bar{\delta}$ はそれぞれ読み取り長さの平均值, 変動係数の平均值, $\overline{\Delta L}$ は見誤 り誤差の平均值で, $r$ は正規乱数の標本值である。なお, $L$ が $x$ 方 向の場合 $L=L_{x}$ とする。 $y$ 方向や ${ }_{e} l_{w}^{j}$ も同様である。また, $\alpha$ は見誤 り誤差の割合であり今回のシミュレーションでは一定值とした。表 1 に手法ごとに各々定めた $\alpha, \bar{\delta}$ の值を示す。最終的に $L_{j},{ }_{e} l_{w}^{j}$ を 式(1b), (2c)に代入し $I_{w}$ を求めた。なお, 前述のように Net 目視診断 法は, 道路側面の 1 方向のみ目視可能な場合が多いため, 1 方向の みのデータで $I_{w}$ を算定する。

\section{2 精度の検討}

式(5a)より求めた見誤り誤差を含んだ $L^{\prime}$ を用いて本診断法により 前述した住宅 128 件の $I_{w}$ を算定した。表 2 につの診断法の中央值, 変動係数, $I_{w}$ が 0.7 未満の住宅の割合 $\left(\right.$ 以下, $\left.\mathrm{P}\left(I_{w}<0.7\right)\right)$ を示す。な お， $I_{w}$ は対数正規分布に従うこと ${ }^{6}$ が知られているため, 表 2 には 平均值ではなく中央值を示した。中央值及び変動係数は Net 目視診 断法が最も高く, 他の方法には大差がない。P $\left(I_{w}<0.7\right)$ は Net 目視診 断法が最も低く, 他の方法には大差がない。これらより, Net 目視 診断法の $I_{w}$ には誤差が大きくかつ過大評価, 寸なわち危険側の評価 となる傾向があることが分かる。さらに， $I_{w}$ に含まれる略算誤差の 傾向をみるため, 表 2 の一般診断法と図面診断法の各值を比較する。 各值とも大差ない。よって, $I_{w}$ の略算誤差は本診断法の精度にさほ ど影響はないと思われる。

続いて, $I_{w}$ に含まれる目視誤差の傾向をみるため, 表 2 の直接目 視診断法あるいは Net 目視診断法と図面診断法の各值を比較する。 直接目視診断法と図面診断法の $I_{w}$ の中央值と変動係数には大差が ない。しかし, $\mathrm{P}\left(I_{w}<0.7\right)$ は $11 \%$ 差がある。また, Net 目視診断法 と図面診断法の $I_{w}$ の各值とも差がある。今までの考察から両目視診 断法には, 見誤り誤差の影響が顕著であると考えられる。加えて, Net 目視診断法は道路面側の 1 方向のみの診断であるという直接目 視診断法にはない要因による誤差が含まれていると考えられる。

次に, 図面診断法と一般診断法の $I_{w}$ に関する相関分析結果を図 4 に示す。同様に直接目視診断法と一般診断法の結果を図 5 に示す。 さらに同様に Net 目視診断法と一般診断法の結果を図 6 に示す。図 4 より,図面診断法と一般診断法との $I_{w}$ の間には相関係数は 0.65 と サンプル数 128 の $1 \%$ 有意水準の 0.23 より大きい有意な相関がある。 先にも述べたが図面診断法には見誤り誤差によって生じる目視誤差 は含まれておらず, したがって, 略算誤差のみが支配的と考えられ る。このような場合, 本診断法で算定した $I_{w}$ は一般診断法の $I_{w}$ と高 い相関を有している。図 5 より, 直接目視診断法と一般診断法の $I_{w}$ に関する相関係数は 0.59 であり一般診断法と図面診断法と同様に
表 1 各手法における $\alpha, \bar{\delta}$

\begin{tabular}{|c|c|c|}
\hline$\alpha$ & 直接目視診断法 & Net目視診断法 \\
\hline $\bar{\delta}$ & -0.08 & -0.12 \\
\hline
\end{tabular}

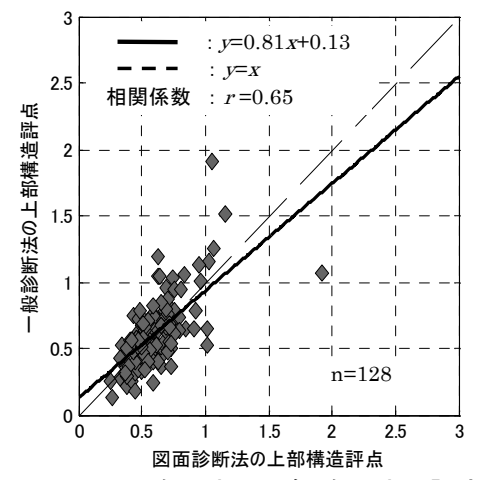

図 4 図面診断法と一般診断法の評点

表 2 各手法における特性值と $I_{w} 0.7$ 未満の住宅の割合

\begin{tabular}{|c|c|c|c|c|}
\hline & 一般診断法 & 図面診断法 & 直接目視診断法 & Net 目視診断法 \\
\hline \hline 中央値 & 0.57 & 0.58 & 0.60 & 0.75 \\
\hline 変動係数 & 0.43 & 0.35 & 0.41 & 0.56 \\
\hline $\mathrm{P}\left(I_{w}<0.7\right)$ & $71 \%$ & $75 \%$ & $64 \%$ & $44 \%$ \\
\hline
\end{tabular}

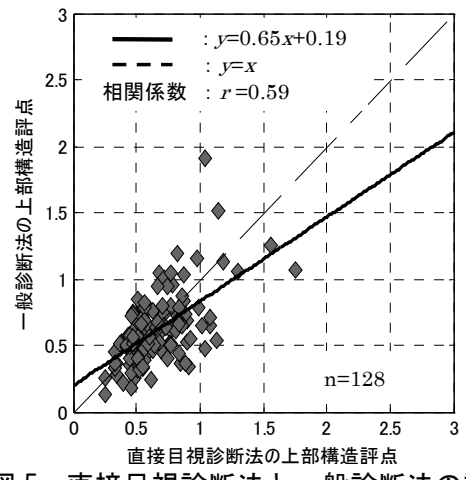

図 5 直接目視診断法と一般診断法の評点

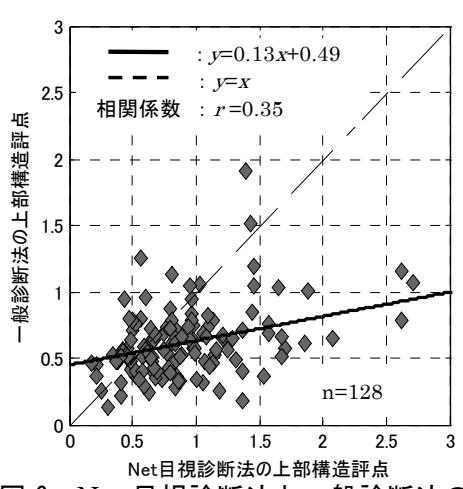

図 6 Net 目視診断法と一般診断法の評点 
$1 \%$ 有意水準で有意な相関がある。しかし, 見誤り誤差の影響により 相相関性は低くなっている。さらに, Net 目視診断法と一般診断法 に関する $I_{w}$ の相関係数は 0.35 であり, $1 \%$ 有意水準で有意な相関が ある。しかし，見誤り誤差の影響で相関性は低くなっており，その 相関性は図 5 の直接目視診断法より低い。これは, 見誤り誤差のほ かに道路面側の 1 方向のみの診断であるという直接目視診断法には ない要因による誤差が含まれているためだと考えられる。なお, こ れらの結果は特性值および $\mathrm{P}\left(I_{w}<0.7\right)$ の結果とほぼ同様である。

これまでの分析を総括すると, 本診断法では見誤り誤差が支配的 であるため, 見誤り誤差をなくすための目視による長さの測り方, 長さの基準になる指標や目視の訓練法などを開発しマニュアル化す る必要があると考えられる。

\section{4. 簡易な耐震診断法の実施例}

本章では，本診断法を適用し実際に住宅の耐震性能に関する情報 収集を行った例を示す。

直接目視診断法を実施した対象地区は，新潟県中越沖地震（2007 年）の被災地である, 新潟県柏崎市内の 3 地区である。それらの地 区の位置を図 7 に示す。それらの地区は, 街の成り立ちの歴史, 寸 なわち古くからの住宅地で古い木造住宅が多い, あるいは新興住宅 地で既存不適格木造住宅が少ないなどといった点に着目して選定し た。具体的には「古くからの集落」である荒浜地区，「古くからの集 落と新興住宅地域の混在」する枇杷島地区,「新興住宅地域」である 半田地区である。それぞれの地区で無作為に抽出した木造住宅 100 件, 計 300 件を対象に目視調查の経験がある男子大学生 3 人, 3 日 間で診断を実施した。なお, 1 日当たりの診断時間は 7 時間であり, 移動手段は徒歩とした。また, 調查時間内では定期的に休養をとり 疲労蓄積をなるべく避けるようにした。各地区の $I_{w}$ の頻度分布を図 8〜10 に示す。各地区の変動係数にはほとんど差はない。中央值, $\mathrm{P}\left(I_{w}<0.7\right)$ は, 荒浜地区 $0.52,62 \%$, 枇杷島地区 $0.65,57 \%$, 半田地 区 $0.75,44 \%$ という結果となった。この事から, 直接目視診断法で 求めた診断值には地域性が確認できる。

次に, Net 目視診断法を実施した対象地区は千葉県船橋市本町で ある。本町地区の位置を図 11 に示す。この街周辺は旧成田街道の宿 場町であったため, 古い木造住宅が密集している。この地区から木 造住宅 100 件を無作為に抽出し, 直接目視診断法の実施と同様に目 視調查の経験がある男子大学生 1 人, 1 日で診断を実施した。なお, 診断時間は昼食を挟んで 2 時間半ずつ合計 5 時間である。また，直

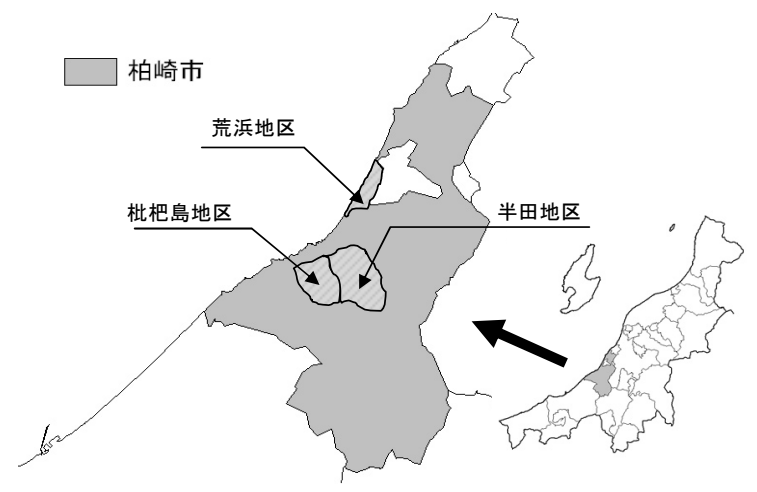

図 7 新潟県柏崎市における 3 地区の立地 ${ }^{7)}$
接目視診断法と同様に調查時間内では定期的に休養をとり疲労蓄積 をなるべく避けるようにした。本町の $I_{w}$ の頻度分布を図 12 に示寸。 中央值 0.81 , 変動係数 $0.48, \mathrm{P}\left(I_{w}<0.7\right) 45 \%$ という結果となった。こ の事から 1 方向のみの診断による $I_{w}$ の特性, 寸なわち, 精度の検討 の結果と同様な傾向が中央值, $\mathrm{P}\left(I_{w}<0.7\right)$ に表れている。これは, Net 目視診断法では 1 方向のみで診断を行う住宅が多いため診断值が過 大評価となるためであり, 今後は, Google マップで情報を得る場合 でも 2 方向について得られるようにする必要があろう。

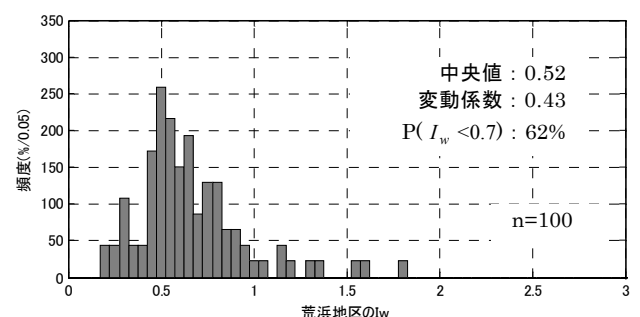

図 8 荒浜地区における $I_{w}$ の頻度分布

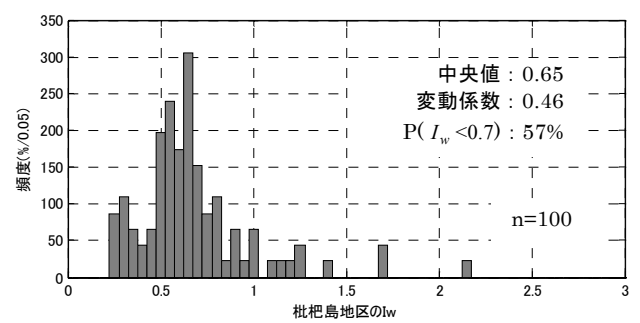

図 9 枇杷島地区における $I_{w}$ の頻度分布

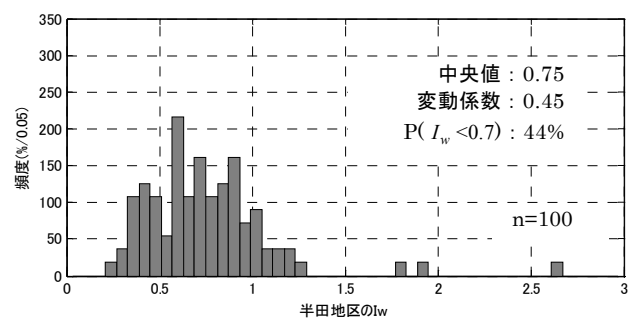

図 10 半田地区における $I_{w}$ の頻度分布

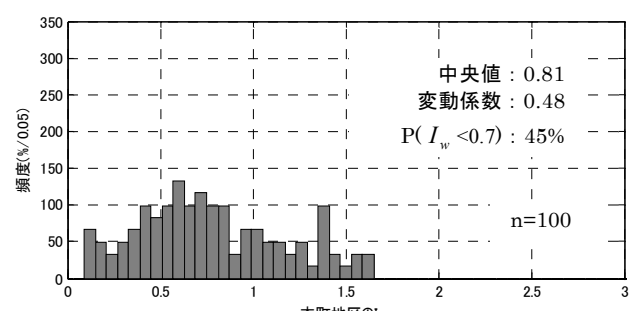

図 12 本町地区における $I_{w}$ の頻度分布

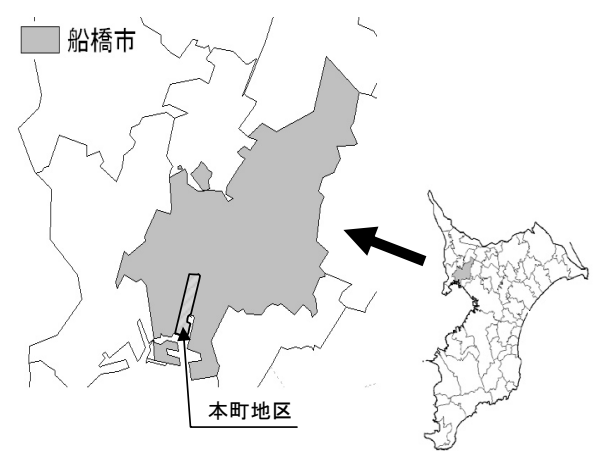

図 11 千葉県船橋市における本町地区の立地 ${ }^{7}$ 


\section{5. まとめ}

本論文は，住宅の耐震性能に関する多くの情報を短期間に収集す るための簡易な耐震診断法を提案し, その精度を検討した。また, その診断法を用いて 4 つの地区で住宅の耐震性能に関する情報収集 を行った例を示した。以下に得られた知見を示す。

(1) 今回の分析に限られるが, 本診断法における $I_{w}$ の略算誤差は特 性值などにそれほど影響がない。

(2) 同様に, 一般診断法と本診断法の間には $1 \%$ 有意水準において 有意な相関性がある。

(3) 見誤り誤差は, 本診断法の結果に対する精度低下の要因となる ため見誤り誤差を減少させる対策が必要である。具体的には, 見誤り誤差をなくすための目視による長さの測り方，長さの基 準になる指標や目視の訓練法などを開発しマニュアル化する必 要があると考えられる。

(4) 本診断法による実施例から本診断法の特性值は対象地区の木造 住宅の耐震性能の特徴を概ね捉えている。

(5) 本診断法による耐震診断実施例から短時間に多くの住宅の耐震 性能を把握できる可能性を示した。

今後は， $\gamma_{r}$ や $D$ を評価する際に生じる情報の見誤りにより $I_{w}$ に 生じる誤差の検討を行い更なる精度の向上, 耐震診断の実施例を増 やすとともに得られた情報で実際に地域防災計画を構築するよう努 めていく。

\section{[参考文献]}

1) 国立国会図書館：住宅而震化の現状と課題, 調査と情報一ISSUE BRIEF 一, 第 568 号, 2007.3

2) 財団法人日本建築防災協会 : 木造住宅の耐震診断と補強方法 木造住宅の 耐震精密診断と補強方法(改訂版), 2004.8

3）塩見政士，小檜山雅之：耐震診断データを用いた木造建物被害関数の等価 線形モデルによる拡張, 日本建築学会技術報告集, 第 13 巻, 第 26 号, 2007.12, p481-486

4) 山口剛史, 森保宏, 井戸田秀樹: 学校建物と木造住宅の耐震化による避難 リスクの低減効果, 日本建築学会東海支部研究報告書, 第 46 号, 2008.2, p149-152

5）萩原幸男: 日本の自然災害一世界の大自然災害も収録－1995 年〜2009 年, 日本専門図書出版，2009.7

6) 中埜良昭, 岡田恒男 : 信頼性理論による鉄筋コンクリート造建築物の耐震 性安全性に関寸る研究, 日本建築学会構造系論文報告集, 第406 号, 1989.12, p37-43

7) 鎌田輝男: 白地図 KenMap, 2009.10

[2010 年 2 月 19 日原稿受理 2010 年 5 月 20 日採用決定］ 